\title{
One of the Possible Causes for Diatom Appearance in Ariake Bay Area in Japan In the Winter from 2010 to 2015 (Clarified with AQUA/MODIS)
}

\author{
Kohei Arai \\ Graduate School of Science and Engineering \\ Saga University \\ Saga City, Japan
}

\begin{abstract}
One of the possible causes for diatom appearance in Ariake bay area I Japan in the winter seasons from 2010 to 2015 is clarified with AQUA/MODIS of remote sensing satellite. Two months (January and February) AQUA/MODIS derived chlorophyll-a concentration are used for analysis of diatom appearance. Match-up data of AQUA/MODIS with the evidence of the diatom appearance is extracted from the MODIS database. Through experiments, it is found that diatom appears after a long period time of relatively small size of red tide appearance. Also, it depends on the weather conditions and tidal effect as well as water current in the bay area in particular.
\end{abstract}

Keywords-chlorophyl-a concentration; red tide; diatom; MODIS; satellite remote sensing

\section{INTRODUCTION}

The Ariake Sea is the largest productive area of Nori (Porphyra yezoensis 1) in Japan. In winters in 2012, 2013, 2014 and 2015, a massive diatom bloom appeared in the Ariake Bay, Japan [1]. In case of above red tides, bloom causative was Eucampia zodiacus 2 . This bloom has being occurred several coastal areas in Japan and is well reported by Nishikawa et al. for Harimanada sea areas [2]-[10]. Diatom blooms have recurrently appeared from late autumn to early spring in the coastal waters of western Japan, such as the Ariake Bay [11] and the Seto Inland Sea [12], where large scale "Nori" aquaculture occurs. Diatom blooms have caused the exhaustion of nutrients in the water column during the "Nori" harvest season. The resultant lack of nutrients has suppressed the growth of "Nori" and lowered the quality of "Nori" products due to bleaching with the damage of the order of billions of yen [3].

In particular in winter since 2012, almost every year, relatively large size of diatoms of Eucampia zodiacus appears in Ariake Bay areas. That is one of the causes for damage of Porphyra yezoensis. There is, therefore, a strong demand to prevent the damage from Nori farmers. Since 2007, Asteroplanus karianus appears in the Ariake Bay almost every year. In addition, Eucampia zodiacus appears in Ariake Bay since 2012. Meanwhile, Eucampia zodiacus did not appeared in 2011, 2010. Therefore, there is a key for the diatom appearance. By comparing Ariake Bay situations in winter seasons in 2010 and 2011 and after 2012, it might be possible to find out possible causes for diatom appearance.

The chlorophyll-a concentration algorithm developed for MODIS ${ }^{3}$ has been validated [13]. The algorithm is applied to MODIS data for a trend analysis of chlorophyll-a distribution in the Ariake Bay in the winter from 2010 to 2015 is made [14]. Also, locality of red tide appearance in Ariake Sea including Ariake Bay, Isahaya Bay and Kumamoto offshore is clarified by using MODIS data derived chlorophyll-a concentration [15]. On the other hand, red tide appearance (location, red tide species, the number of cells in unit water volume by using microscopy) are measured from the research vessel of the Saga Prefectural Fishery Promotion Center: SPFPC by once a 10 days. The location and size of the red tide appearance together with the red tide source would be clarified by using SPFPC data. Match-up data of MODIS derived chlorophyll-a concentration is used for investigation of relations between MODIS data and truth data of the red tide appearance. Through time series data analysis of MODIS derived chlorophyll-a concentration, one of the possible causes of diatom appearance is clarified with the evidence of research Bessel observations.

In the next section, the method and procedure of the experimental study is described followed by experimental data and estimated results. Then conclusion is described with some discussions.

\section{EXPERIMENTAL METHOD AND RESULTS}

\section{A. Intensive Study Areas}

Fig.1 shows the intensive study areas of Ariake Bay, Kyushu, Japan. Ariake Bay is a portion of Ariake Sea of which the width is around $20 \mathrm{~km}$ (in direction of east to west) and the length is approximately $100 \mathrm{~km}$ (in direction of north to south). It is almost closed sea area because the mouth of Ariake Sea is quite narrow. Sea water exchanges are, therefore, very small.

\footnotetext{
${ }_{2}^{1}$ http://en.wikipedia.org/wiki/Porphyra

http://www.eos.ubc.ca/research/phytoplankton/diatoms/centric/eucampia/e_zo diacus.html
}

\footnotetext{
${ }^{3}$ http://modis.gsfc.nasa.gov/
} 


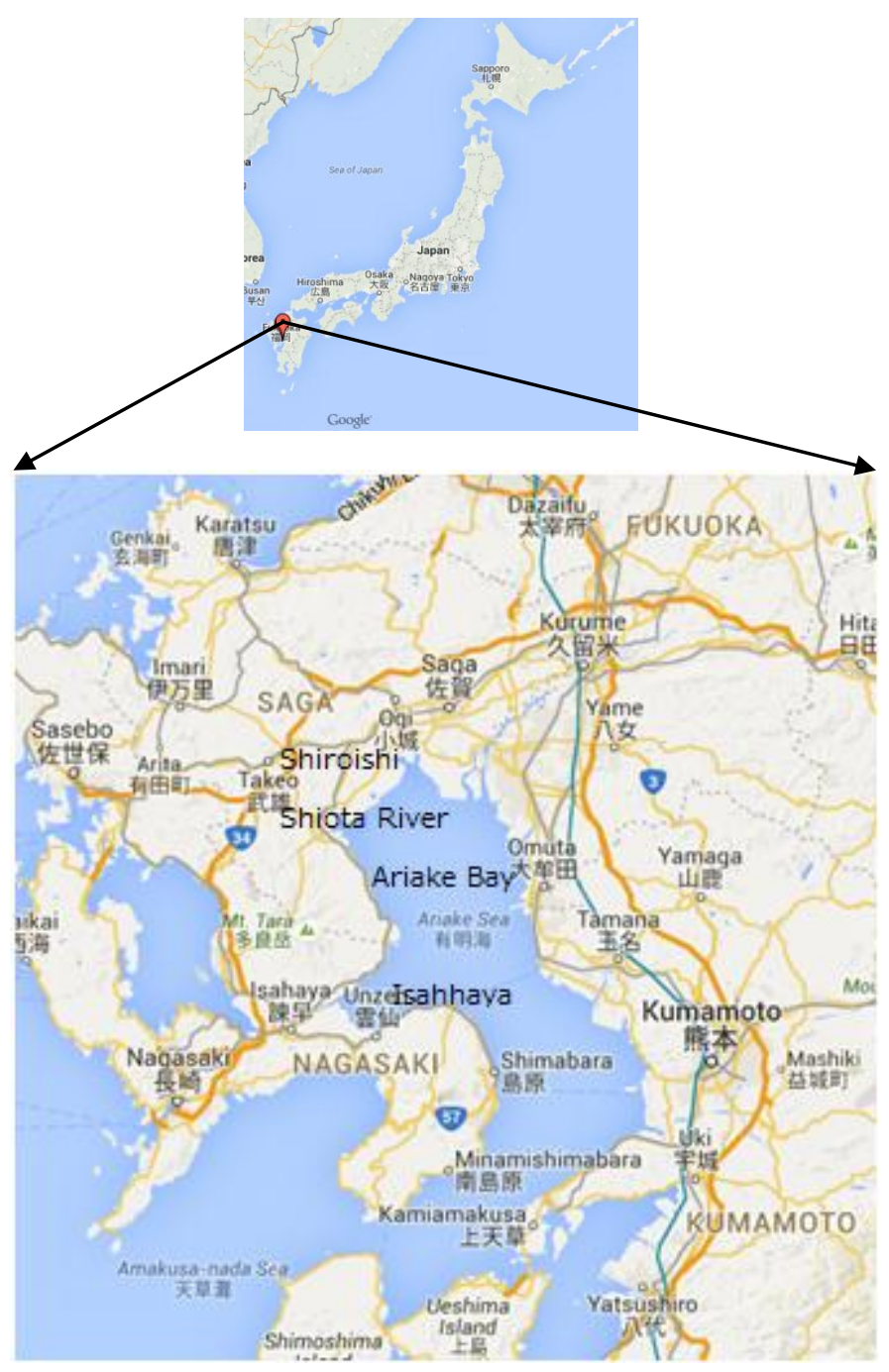

Fig. 1. Intensive study areas

\section{B. MODIS Data Derived Chlorophyll-a Concentration and}

Truth Data and Truth Data of Red Tide in 2010 to 2015

MODIS derived chlorophyll-a concentration which area acquired for the observation period of two months (in January and February) in 2010 to 2015 is used for the experiments. On the other hand, Fig.2 shows the example of the superimposed image with MODIS data derived chlorophyll-a concentration and truth data which is provided by Saga Prefectural Fishery Promotion Center on 21 January 2010. The number in the figure denotes the number of red tide cells / $\mathrm{ml}$. Such the number of red tide is reported every 10 days.

It is found the following red tide at around the Shiota river mouth and its surrounding areas on January 21 2010,

\section{Asterionella kariana; 3280 cells $/ \mathrm{ml}$}

\section{Skeletonema costatum: 1330 cells/ml}

On January11 2011, it is found the following red tide along with the Shiroishi town offshore to the Shiota river mouth and its surrounding areas,

Asterionella kariana; 10150 cells $/ \mathrm{ml}$

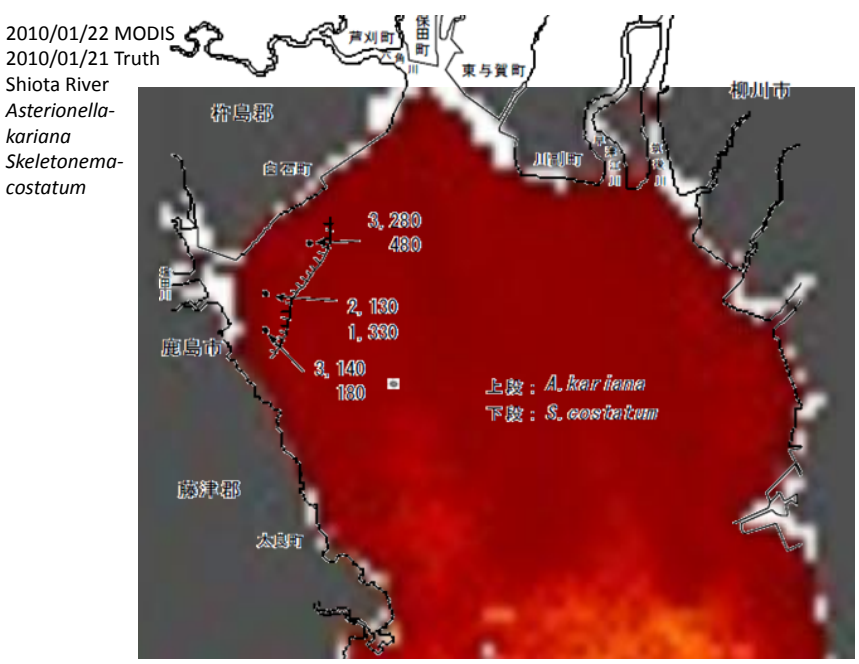

Fig. 2. Example of the superimposed image with MODIS data derived chlorophyll-a concentration and truth data which is provided by Saga Prefectural Fishery Promotion Center

Although the truth data say that the red tide is distributed at around Shiota river mouth and its surrounding areas as well as Shiroishi offshore, it cannot be seen due to the fact that it is covered with cloud in the MODIS data derived chlorophyll-a concentration. It is found the following red tide at around the Kashima offshore on February 25 2011,

Asterionella kariana; 4950 cells/ml

It is found the following red tide at around the Shiota River Mouth and its surrounding areas on December 30 2011,

Asterionella kariana; 5150 cells $/ \mathrm{ml}$

On January 23 2012, it is found the following red tide at the Shiroishi offshore,

\section{Skeletonema spp .: 5150 cells $/ \mathrm{ml}$}

The red tide is distributed at around Shiota river mouth and its surrounding areas as well as Shiroishi offshore.

The following red tide is found widely along with the Kawazoe offshore to the Tara offshore on February 22 2012,

Eucampia zodiacus: 1,090 cells/ml

Also it is found the following red tide along with the Shiota river mouth and its surrounding areas to the Kashima offshore on December 31 2012,

\section{Skeletonema spp .: 6110 cells $/ \mathrm{ml}$}

On January 7 2013, the following red tide are observed along with the Shiota river mouth and its surrounding areas to the Shiroishi offshore,

\section{Asterionella kariana; 5630 cells/ml}

\section{Skeletonema costatum: 3390 cells $/ \mathrm{ml}$}

The red tide distribution derived from MODIS data is almost coincident to the truth data.

It is found the following red tide at the Shiroishi offshore on January 62014 , 


\section{Asterionella kariana; 4830 cells/ml}

The following red tide is observed at the Shiroishi offshore on January 162014 ,

\section{Skeletonema spp .: 6110 cells/ml \\ Thalassiosira spp.: 1510 cells/ml}

On February 6 2014, the following red tide is observed almost whole Ariake bay area except the Shiroishi offshore,

\section{Eucampia zodiacus: 568 cells/ml}

It is observed the following red tide along with the Shiroishi offshore to the Tara offshore on December 302014 ,

\section{Asterionella kariana; 3890 cells/ml}

\section{Skeletonema costatum: 8750 cells/ml}

On March 6 2015, the following red tide is observed along with the Kashima offshore to the Tara offshore,

\section{Eucampia zodiacus: 1310 cells/ml}

It is clear that the diatom of Eucampia zodiac appeared in the winter in 2012, 2013, 2014 and 2015. The differences between the situations in the time period of 2010, 2011 and the other time period from 2012 to 2015 are (1) relatively small size of red tides, Asterionella kariana and Skeletonema costatum appeared at around Shiota river mouth and its surrounding areas for a long time period, (2).

\section{Chlorophyll-a Concentration Trends in the Different Areas} in theWInter of the Different Year

Chlorophyll-a concentration trends in the different areas, Isahaya Bay, Around the Shiota river mouth and its surrounding areas, and the middle of the Ariake Bay are investigated with the MODIS derived chlorophyll-a concentrations acquired on

(2010) January 1, 3, 9, 14, 16, 17, 18, 22, 24, 26, 27, 29, February 3, 4, 5, 6, 20, 21, 23, and 28 in 2010

(2011) January 1, 2, 7, 8, 14, 17, 22, 26, 27, February 1, 3, $4,15,21,22,24$, and 26 in 2011

(2012) January 2, 6, 7, 12, 17, 20, 21, 23, 26, 29, 30, 31, February 4, 11, 12, 20, 24, and 29 in 2012

(2013) January 4, 6, 10, 11, 12, 15, 18, 25, 28, 30, 31, February 2, 3, 10, 13, 16, 20, 22, 23, 24, and 29 in 2013

(2014) January 10, 13, 15, 16, 19, 23, 24, 26, 27, 29, 30, February 4, 8, 11, 12, 20, 21, 23, and 24 in 2014

(2015) January 4, 6, 7, 8, 9, 10, 12, 17, 18, 20, 23, February 1, 3, 6, 9, 13, 14, 20, and 27 in 2015

The results from the trend analysis are shown in Fig.3.

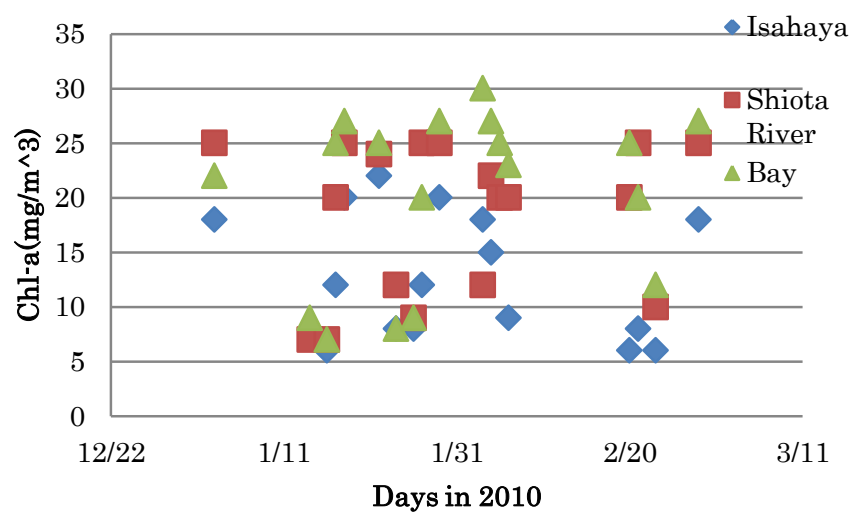

(a) 2010

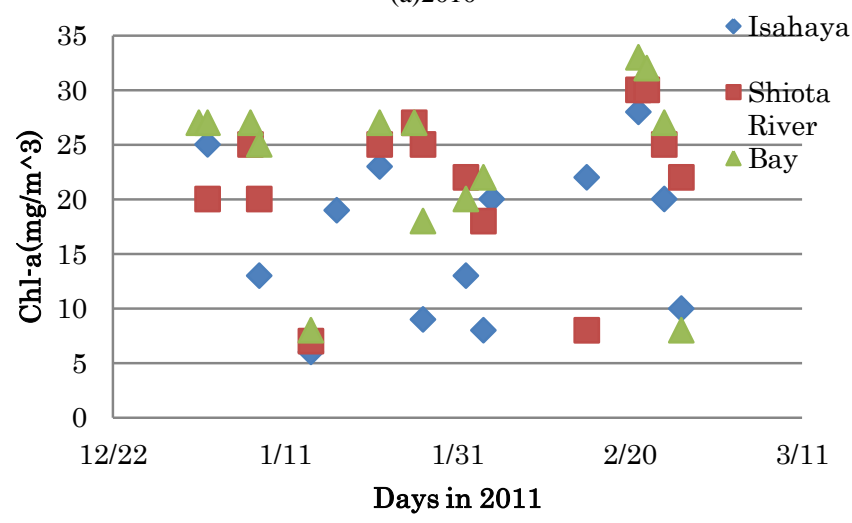

(b) 2011

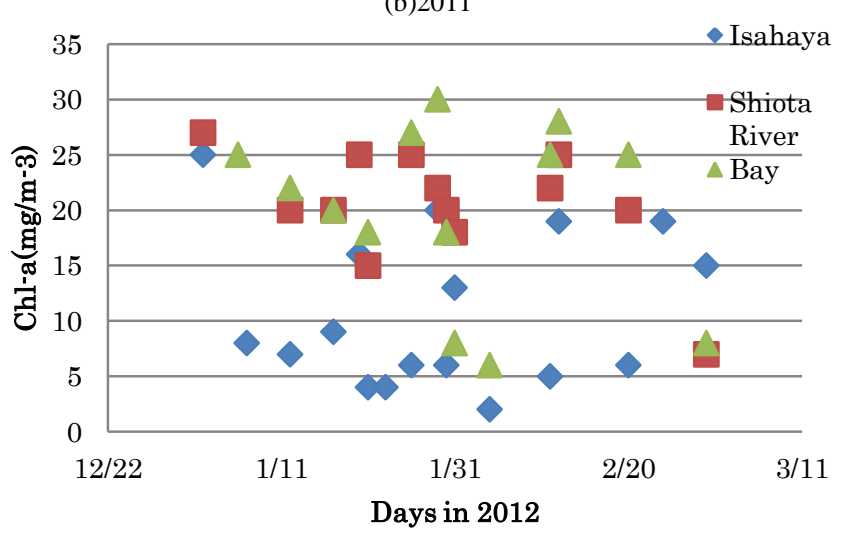

(c) 2012

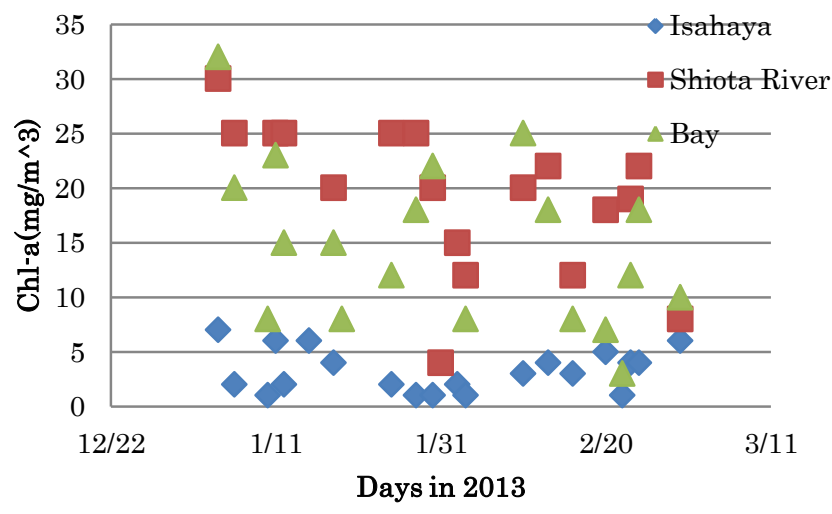

(d) 2013 


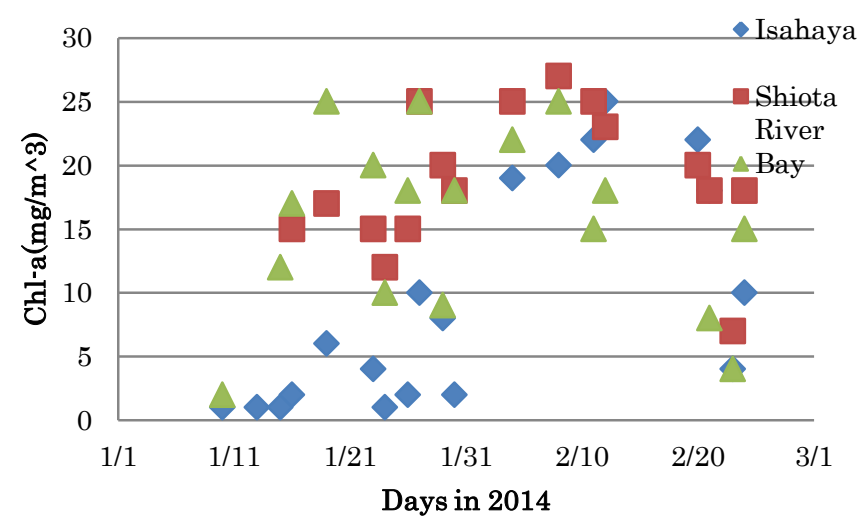

(e) 2014

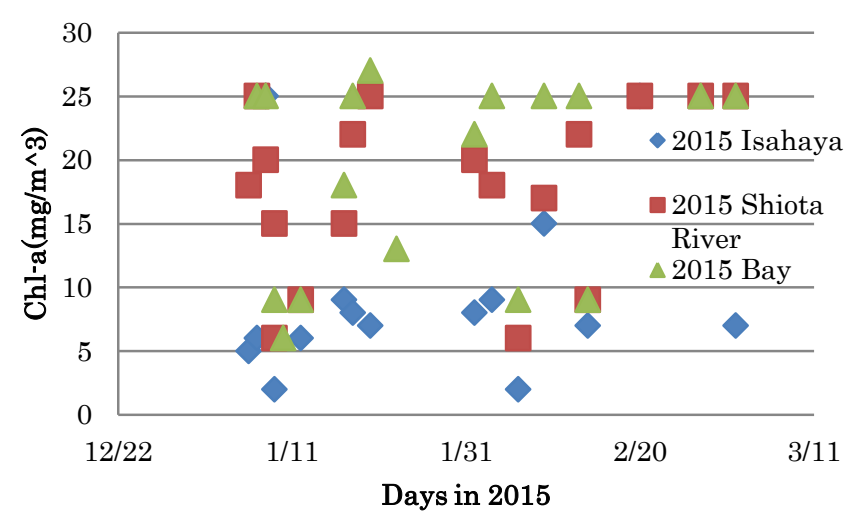

(f) 2015

Fig. 3. Trends of chlorophyll-a concentration derived from MODIS data in the winter seasons in 2010-2015

The trends of chlorophyll-a concentrations of Shiota river mouth and its surrounding areas and the middle of Ariake Bay area are quite similar while that of Isahaya Bay area is not resemble to those of the trends of Shiota river mouth and its surrounding area and Ariake Bay area. Therefore, the origin of chlorophyll-a of Isahaya Bay area is different from those of Ariake Bay area as well as Shiota river mouth and its surrounding areas. Not only time series of trend of chlorophyll-a concentrations, but also spatial characteristics of chlorophyll-a concentration distributions between Isahaya Bay and the other Ariake Bay area as well as Shiota river mouth and its surrounding areas are different each other.

Relatively large sized diatom of Eucampia zodiacus: appeared in entire Ariake Bay areas in 2012, 2013, 2014, and 2015 and it did not appeare in 2010 and 2011. Comparatively small sized diatom of Asterionella kariana and Skeletonema costatum, on the other hand, appeared almost every year though. In particular, large sized diatom appeared after small sized diatom appeared for a long time period in the winter seasons in year of 2012, 2013, 2014, and 2015. On the other hand, small sized diatom disappeared in a short time period in the winter seasons in years of 2010 and 2011 results in large sized diatom did not appeared.

\section{Relations Between Chlorophyll-a Concentration and the Meteorological Data}

It may say that red tide appears when the following conditions are situated, nutrition rich water and rich solar illumination and less wind. Therefore, the relations between chlorophyll-a concentration and rainfall in a day, averaged airtemperature in a day, and the averaged wind speed in a day are investigated together with MODIS data derived 8 day composite of the Photosynthetically Available Radiance: PAR (Einstein/ $\mathrm{m}^{2} /$ day). The meteorological data are gotten from the Japanese Meteorological Agency: JMA of Shiroishi Automated Meteorological Data Acquisition System: AMEDAS data ${ }^{4}$ which meteorological station is situated at the longitude and latitude of 33:11.0' North and 130:8.9' East. The elevation of the station is $2 \mathrm{~m}$. The results from these analyses are shown in Fig.4. Meanwhile, MODIS data derived PAR is obtained from the NASA/GSFC site $^{5}$. Solar illumination condition can be replaced to PAR.
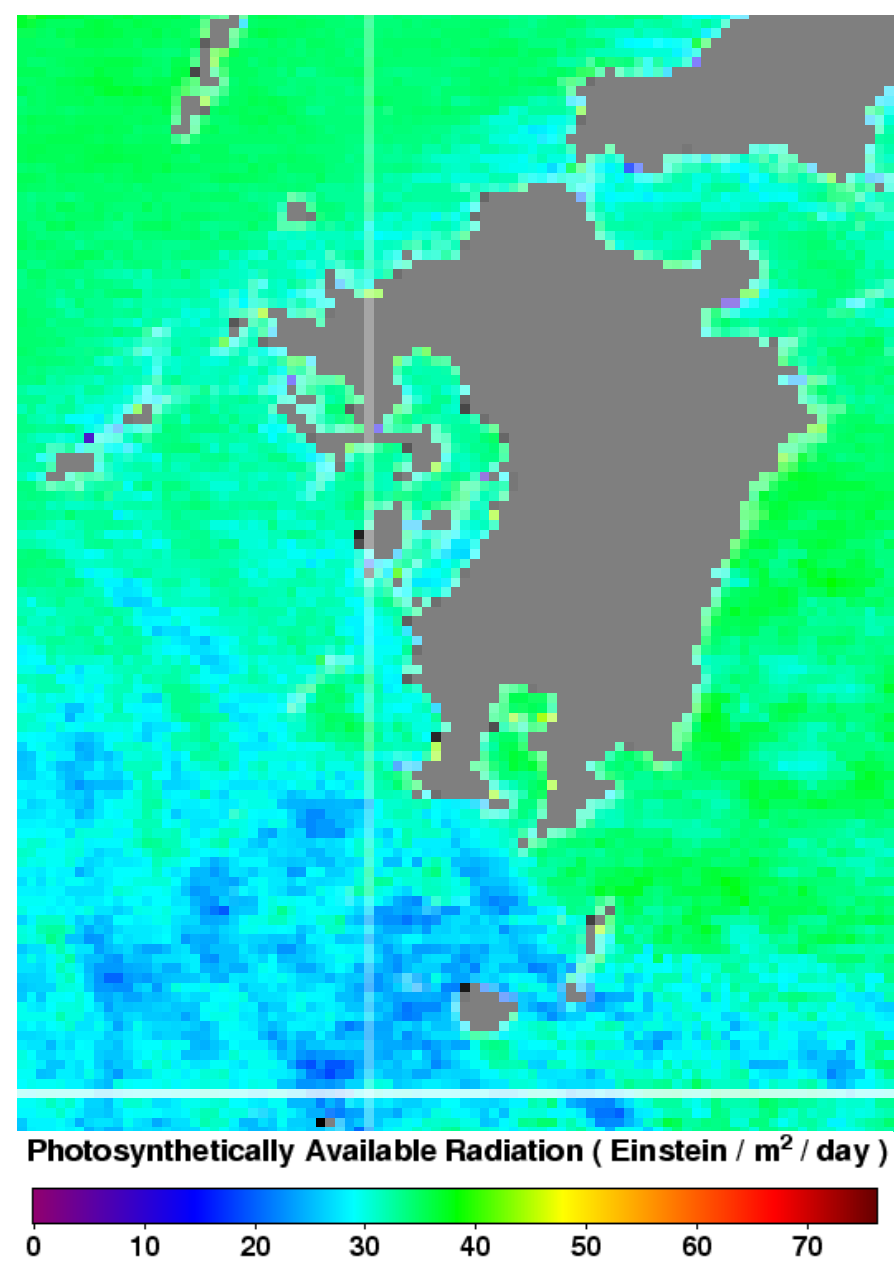

Fig. 5. Example of the 8 day composite of the PAR derived from MODIS data for the period from March 6 to March 14 in 2011

\footnotetext{
${ }_{5}^{4}$ http://www.data.jma.go.jp/obd/stats/etrn/index.php

http://oceancolor.gsfc.nasa.gov/cgi/13?per=8D\&prd=PAR_par\&sen=T\&res $=4$ $\mathrm{km} \&$ num $=24 \& \operatorname{ctg}=$ Standard $\&$ date $=1 \mathrm{Jan} 2014$
} 
Eucampia zodiacus may grow a wide variety of water temperature and salinity conditions, the most preferable water temperature is around $25^{\circ} \mathrm{C}$ tough. In order to grow, Eucampia zodiacus requires relatively strong solar illumination. It can maintain capability of consume nitrogen even if the water temperature is not so high. Therefore, the conditions of water temperature, solar illumination are key issues for Eucampia zodiacus
One the other hand, rainfall provide nutrient to the Bays from the rivers. Therefore, Eucampia zodiacus did not appear in 2010 and 2011 because of less of the rainfall while Eucampia zodiacus appeared in 2012 and after because of rich of the rainfall.

Meanwhile, PAR in the first half of January in both 2010 and 2011 is relatively small in comparison to the PAR in that period in 2012 and after. Therefore, diatom did not appear in both 2010 and 2011.

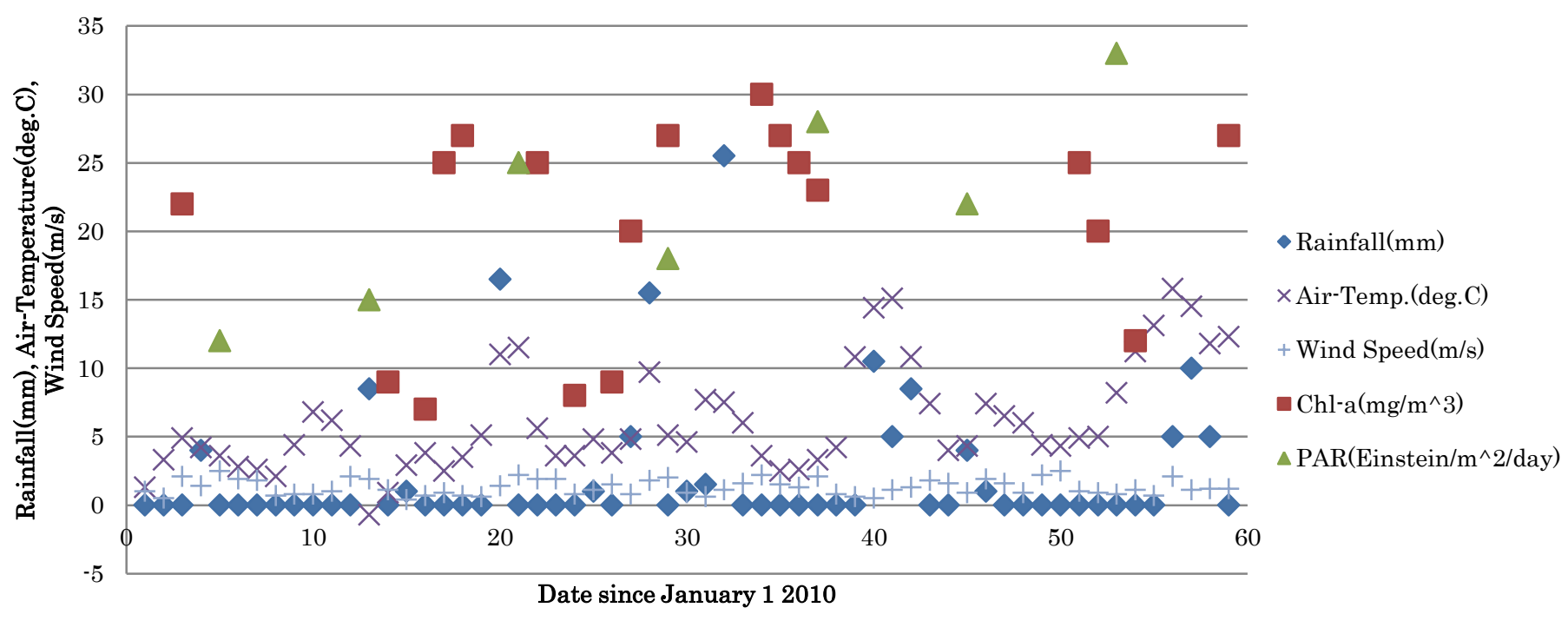

(a) 2010

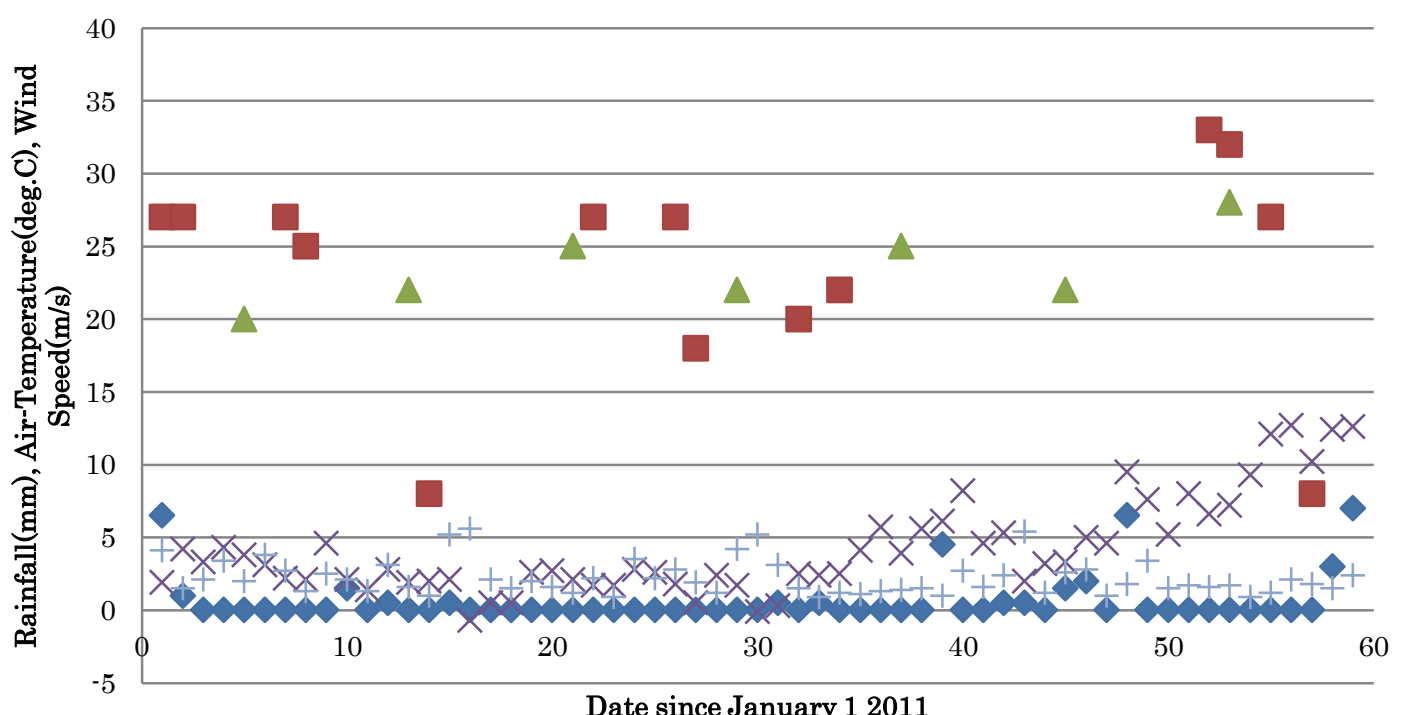

Rainfall(mm)

$\times$ Air-Temp.(deg.C)

+ Wind $\operatorname{Speed}(\mathrm{m} / \mathrm{s})$

- $\mathrm{Chl}-\mathrm{a}\left(\mathrm{mg} / \mathrm{m}^{\wedge} 3\right)$

$\triangle \mathrm{PAR}\left(\right.$ Einstein $/ \mathrm{m}^{\wedge} 2 /$ day $)$

(b) 2011 


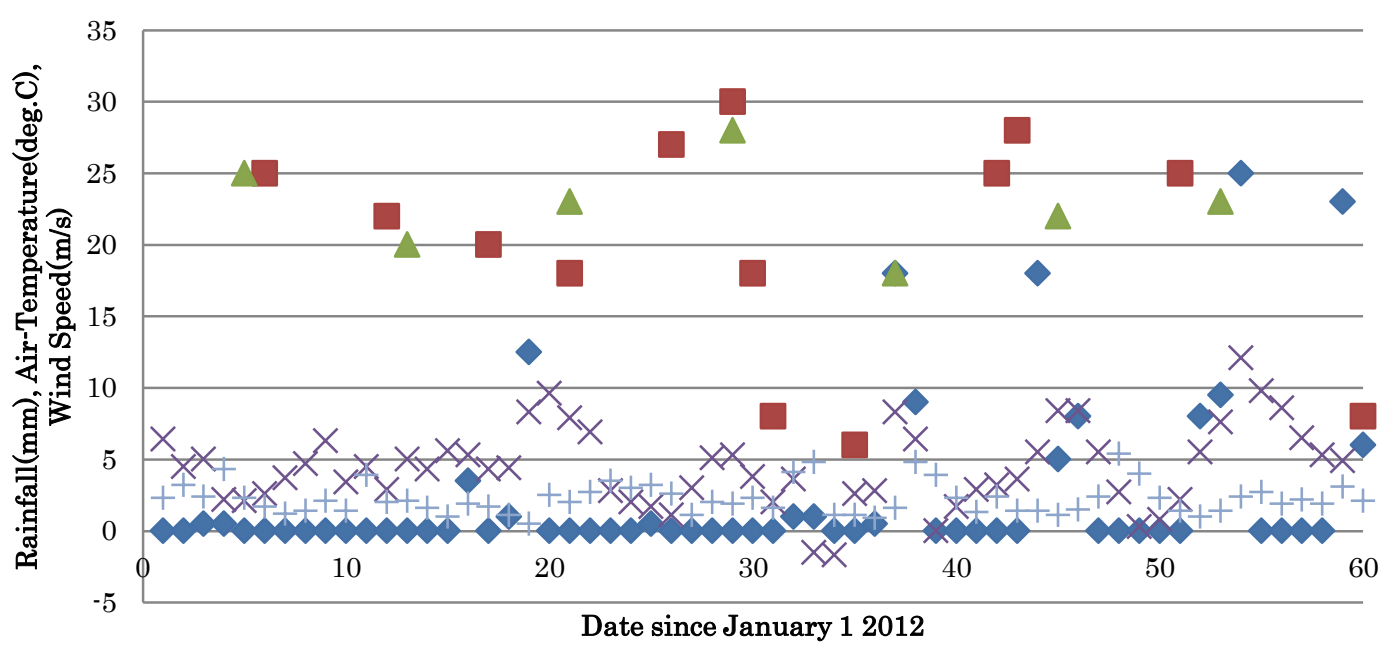

(c) 2012

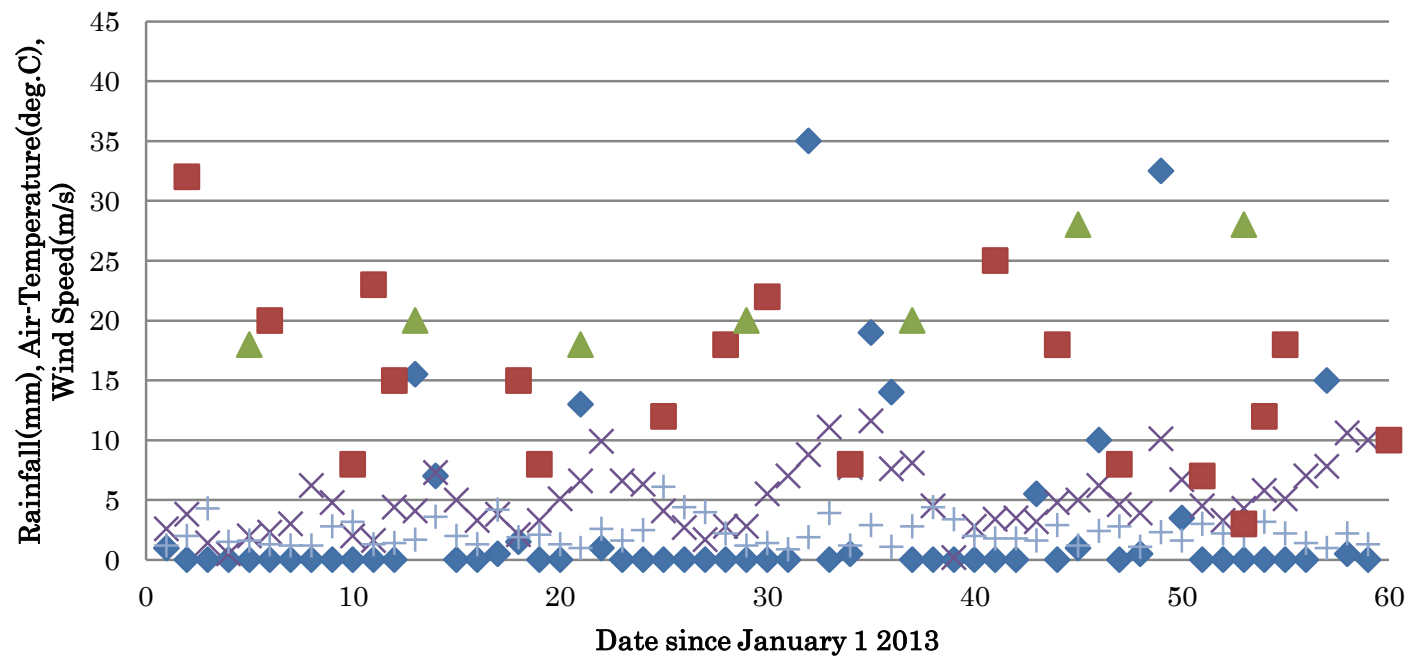

(d) 2013

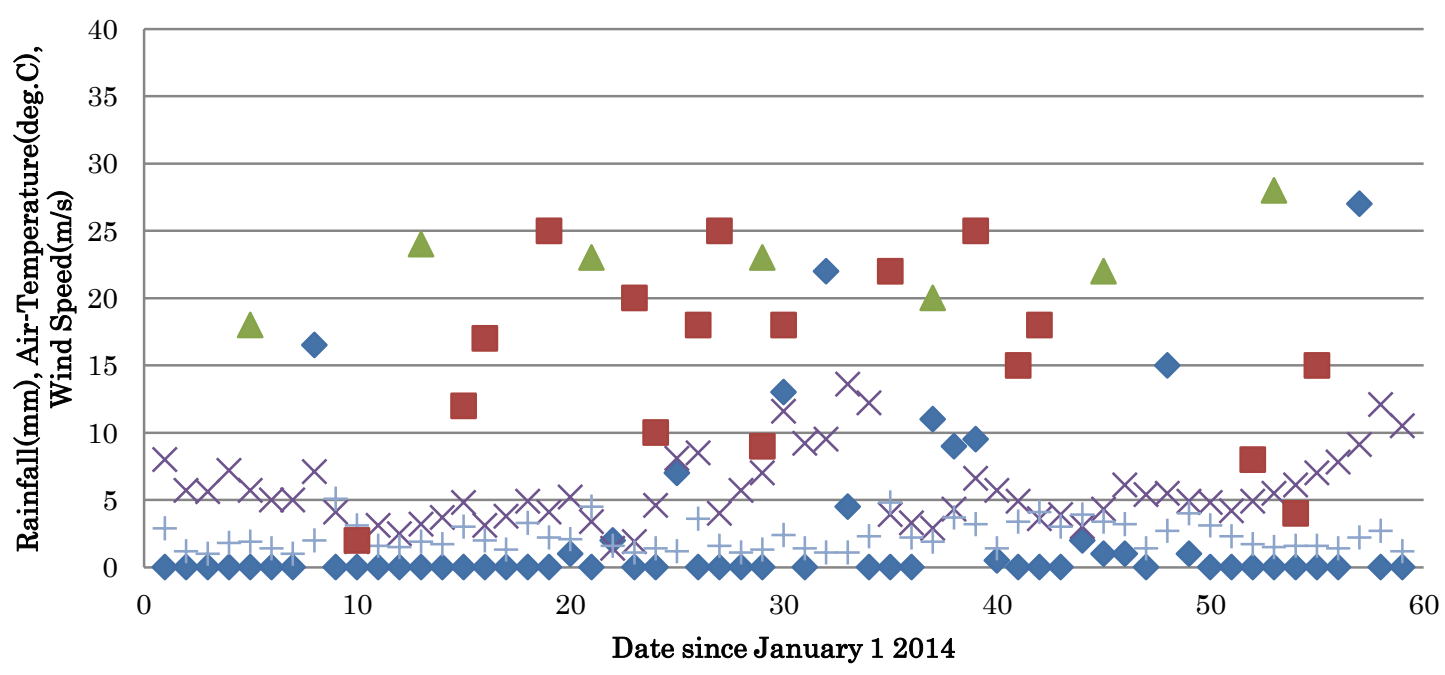

(e) 2014
- Rainfall(mm)

$\times$ Air-Temp.(deg.C)

+ Wind $\operatorname{Speed}(\mathrm{m} / \mathrm{s})$

- $\mathrm{Chl}-\mathrm{a}\left(\mathrm{mg} / \mathrm{m}^{\wedge} 3\right)$

$\triangle \mathrm{PAR}($ Einstein/m^2/day)

- Rainfall(mm)

$\times$ Air-Temp.(Deg.C)

+ Wind Speed $(\mathrm{m} / \mathrm{s})$

- Chl-a $\left(\mathrm{mg} / \mathrm{m}^{\wedge} 3\right)$

$\triangle \operatorname{PAR}\left(\right.$ Einstein $/ \mathrm{m}^{\wedge} 2 /$ day $)$

- Rainfall(mm)

$\times$ Air-Temp.(deg.C)

+ Wind $\operatorname{Speed}(\mathrm{m} / \mathrm{s})$

- Chl-a(mg/m^3)

$\triangle \operatorname{PAR}\left(\right.$ Einstein $/ \mathrm{m}^{\wedge} 2 /$ day $)$ 


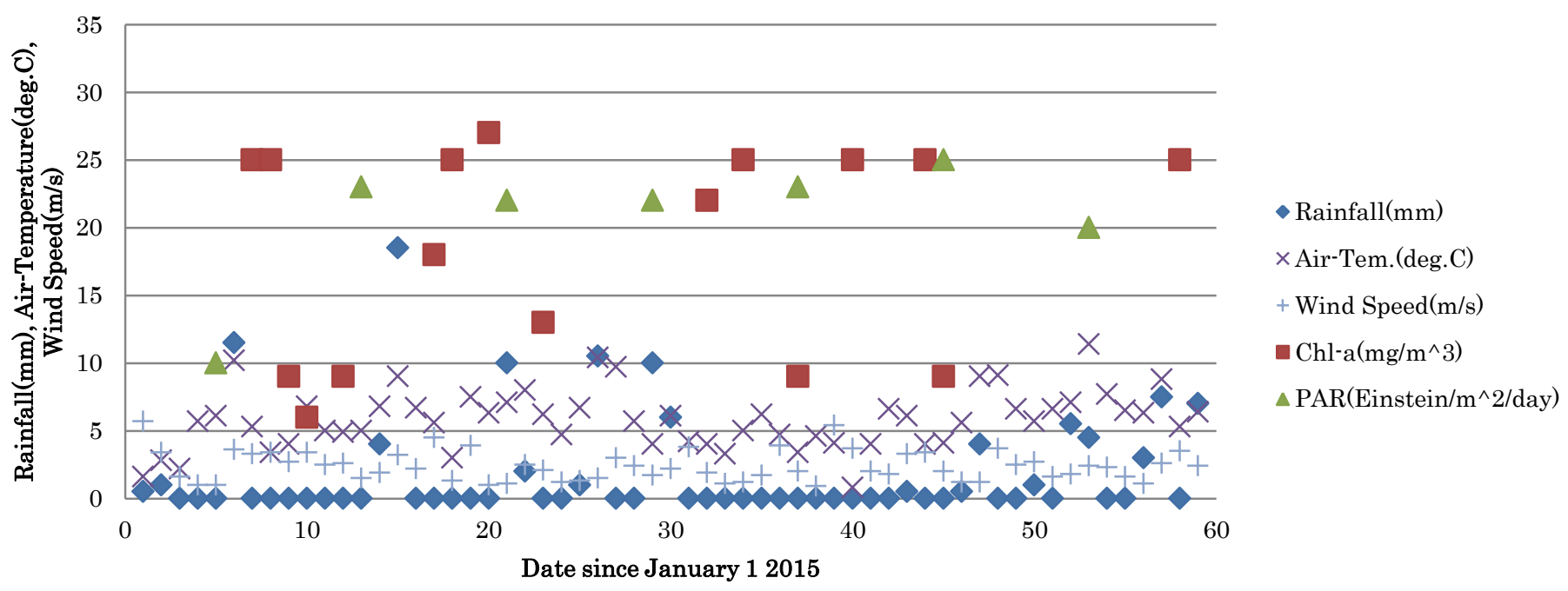

(f) 2015

Fig. 4. Trends of meteorological data and chlorophyll-a concentration in the winter seasons of 2010 to 2015

\section{CONCLUSION}

Asterionella kariana and Skeletonema costatum are used to be appeared in the Ariake Bay area in the winter seasons followed by Eucampia zodiacus appearance in the early spring almost every year after 2012 in particular, on February 22 2012, February 26 2013, February 62014 and March 62015.

Through the trend analysis with the superimposed images of the truth data and the MODIS data derived chlorophyll-a concentration which are acquired in the period starting from February 27 to March 5 2015, it is found that chlorophyll-a is distributed densely in the Ariake bay area and Isahaya bay area on February 27. Then the densely distributed chlorophyll$\mathrm{a}$ is flown to the south direction along with the sea water current in the Ariake bay while the densely distributed chlorophyll-a is flown from the Isahaya bay to the Tara-machi and far beyond the Shimabara offshore. Therefore, it may say that the sources of red tide are different between Ariake bay and Isahaya bay.

Further investigations are required to clarify the mechanism of red tide appearance with the consideration three dimensional of cross section analysis the red tide source movement.

\section{ACKNOWLEDGMENT}

The authors would like to thank Dr. Toshiya Katano of Tokyo University of Marine Science and Technology, Dr. Yuichi Hayami, Dr. Kei Kimura, Dr. Kenji Yoshino, Dr. Naoki Fujii and Dr. Takaharu Hamada of Institute of Lowland and Marine Research, Saga University for their great supports through the experiments.

\section{REFERENCES}

[1] Yuji Ito, Toshiya Katano, Naoki Fujii, Masumi Koriyama, Kenji Yoshino, and Yuichi Hayami, Decreases in turbidity neap tides initiate late winter large diatom blooms in a macrotidal embayment, Journal of Oceanography,69: 467-479. 2013.

[2] Nishikawa T (2002) Effects of temperature, salinity and irradiance on the growth of the diatom Eucampia zodiacus caused bleaching seaweed Porphyra isolated from Harima-Nada, Seto Inland Sea, Japan. Nippon Suisan Gakk 68: 356-361. (in Japanese with English abstract)

[3] Nishikawa $T$ (2007) Occurrence of diatom blooms and damage tocultured Porphyra thalli by bleaching. Aquabiology 172: 405-410. (in Japanese with English abstract)

[4] Nishikawa T, Hori Y (2004) Effects of nitrogen, phosphorus and silicon on the growth of the diatom Eucampia zodiacus caused bleaching of seaweed Porphyra isolated from Harima-Nada, Seto Inland Sea, Japan. Nippon Suisan Gakk 70: 31-38. (in Japanese with English abstract)

[5] Nishikawa T, Hori Y, Nagai S, Miyahara K, Nakamura Y, Harada K, Tanda M, Manabe T, Tada K (2010) Nutrient and phytoplankton dynamics in Harima-Nada, eastern Seto Inland Sea, Japan a 35-year period from 1973 to 2007. Estuaries Coasts 33: 417-427.

[6] Nishikawa T, Hori Y, Tanida K, Imai I (2007) Population dynamics of the harmful diatom Eucampia zodiacus Ehrenberg causing bleachings of Porphyra thalli in aquaculture in Harima- Nada, the Seto Inland Sea, Japan. Harmful algae 6: 763-773.

[7] Nishikawa T, Miyahara K, Nagai S (2000) Effects of temperature and salinity on the growth of the giant diatom Coscinodiscus wailesii isolated from Harima-Nada, Seto Inland Sea, Japan. Nippon Suisan Gakk 66: 993-998. (in Japanese with English abstract)

[8] Nishikawa T, Tarutani K, Yamamoto T (2009) Nitrate and phosphate uptake kinetics of the harmful diatom Eucampia zodiacus Ehrenberg, a causative organism in the bleaching of aquacultured Porphyra thalii. Harmful algae 8: 513-517.

[9] Nishikawa T, Yamaguchi M (2006) Effect of temperature on lightlimited growth of the harmful diatom Eucampia zodiacus Ehrenberg, a causative organism in the discoloration of Porphyra thalli. Harmful Algae 5: 141-147.

[10] Nishikawa T, Yamaguchi M (2008) Effect of temperature on lightlimited growth of the harmful diatom Coscinodiscus wailesii, a causative organism in the bleaching of aquacultured Porphyra thalli. Harmful Algae 7: 561-566.

[11] Syutou T, Matsubara T, Kuno K (2009) Nutrient state and nori aquaculture in Ariake Bay. Aquabiology 181: 168-170. (in Japanese with English abstract)

[12] Harada K, Hori Y, Nishikawa T, Fujiwara T (2009) Relationship between cultured Porphyra and nutrients in Harima-Nada, eastern part of the Seto Inland Sea. Aquabiology 181: 146-149. (in Japanese with English abstract)

[13] Arai K., T. Katano, Trend analysis of relatively large diatoms which appear in the intensive study area of the ARIAKE Sea, Japan, in winter (2011-2015) based on remote sensing satellite data, Internationa Journal 
of Advanced Research in Artificial Intelligence (IJARAI), 4, 7, 15-20, 2015.

[14] Arai, K., Locality of Chlorophyll-a Concentration in the Intensive Study Area of the Ariake Sea, Japan in Winter Seasons Based on Remote Sensing Satellite Data, Internationa Journal of Advanced Research in Artificial Intelligence (IJARAI), 4, 8, 18-25, 2015.

\section{AUTHORS PROFILE}

Kohei Arai, He received BS, MS and PhD degrees in 1972, 1974 and 1982, respectively. He was with The Institute for Industrial Science and Technology of the University of Tokyo from April 1974 to December 1978 also was with National Space Development Agency of Japan from January,
1979 to March, 1990. from 1985 to 1987 , he was with Canada Centre for Remote Sensing as a Post Doctoral Fellow of National Science and Engineering Research Council of Canada. He moved to Saga University as a Professor in Department of Information Science on April 1990. He was a councilor for the Aeronautics and Space related to the Technology Committee of the Ministry of Science and Technology from 1998 to 2000. He was a councilor of Saga University for 2002 and 2003. He also was an executive councilor for the Remote Sensing Society of Japan for 2003 to 2005 . He is an Adjunct Professor of University of Arizona, USA since 1998. He also is Vice Chairman of the Commission "A" of ICSU/COSPAR since 2008. He wrote 33 books and published 510 journal papers. He is now Editor-in-Chief of IJACSA and IJISA. http://teagis.ip.is.saga-u.ac.jp/index.html 